\section{Expanded research to target E. coli outbreaks}

$\mathrm{UC}$ and federal scientists have proposed ramping up a long-planned study of E. coli in Monterey County to include areas of San Benito County where spinach implicated in the September 2006 E. coli outbreak might have been grown.

By January, the team will begin collecting thousands of samples of domestic animal and wildlife droppings; creek, ditch and irrigation water; and soil and lettuce from farms. The investigators are now hammering out the details of a proposal to expand the research effort by about $50 \%$, encompassing the larger territory.

The original 4-year study was funded in October 2006 with a $\$ 1.17$ million research grant from the USDA-Cooperative State Research, Education and Extension Service. When the funding was first requested, the focus was on a series of E. coli outbreaks from 1995 to 2005 across the nation, seven associated with farms in the Salinas Valley. Fifteen outbreaks were related to lettuce (see page 6) and one to spinach. However, the late September 2006 spinach outbreak captured national headlines and increased calls for research to prevent future E. coli crises.

In the September 2006 outbreak, 204 cases of illness due to E. coli O157:H7 in spinach were reported to the U.S. Centers for Disease Control and Prevention (CDC), including three deaths and 102 hospitalizations. Food safety experts estimate that only one of 20 such illnesses is reported to the CDC; the actual number of people sickened in this outbreak was more likely about 4,000. (E. coli O157:H7 is one of many illnesses monitored by the CDC; see table.)

The economic impact on spinach growers has been tremendous. The United Fresh Produce Association estimated that losses to processors alone reached $\$ 50$ million to $\$ 100$ million. That does not include losses to growers or retailers of spinach or other fresh-cut products.

Although the source of the E. coli O157:H7 that contaminated spinach and the exact farm where the spinach was contaminated have not yet been confirmed, the California Department of Health Services (DHS) has investigated four farms and ranches in San Benito and Monterey counties. During a press conference call on Oct. 26, 2006, Kevin Reilly of DHS confirmed that E. coli O157:H7 isolates found in wild pig feces, the feces of several cows, and in a stream on one of the four farms were genetically identical to the strain that caused the deaths and serious illnesses related to spinach. Although the specific mechanism of contamination remains unknown, wild pigs could explain how E. coli O157:H7 spread from cattle on the ranch to

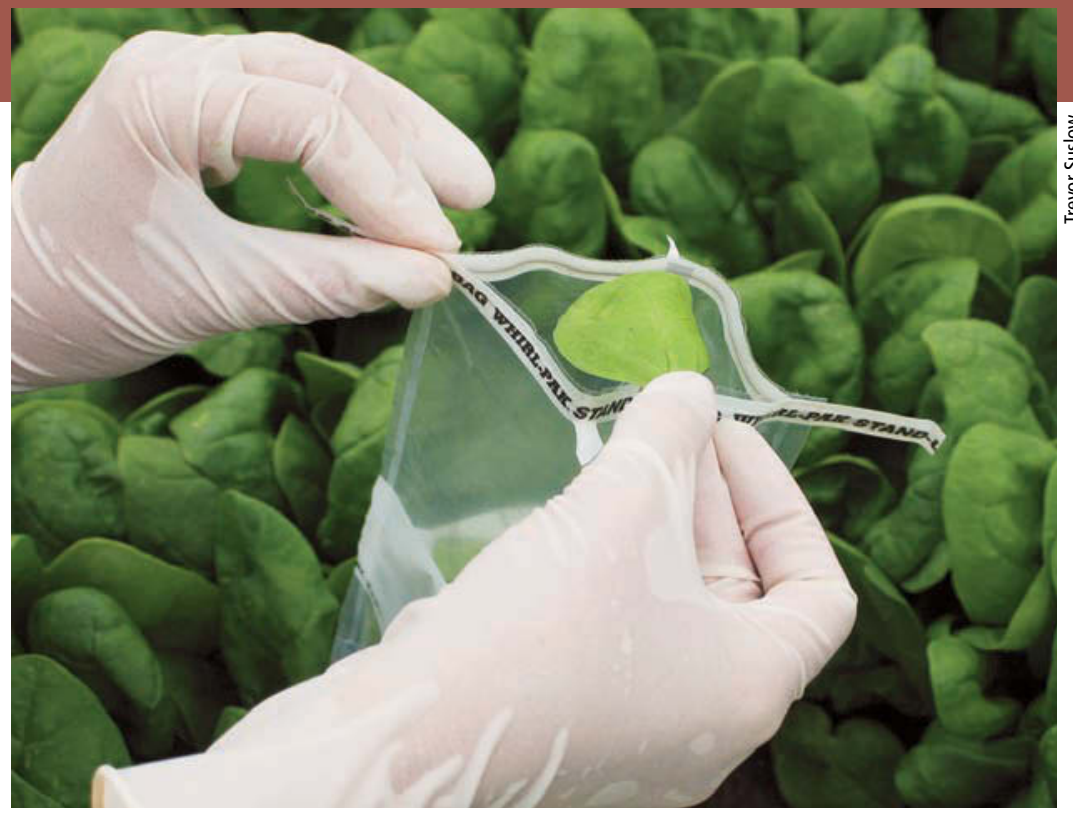

the spinach field, which was just under a mile away, Reilly said. The pigs could have tracked the bacteria into the field or spread it through their droppings.

The news was of great interest to Edward (Rob) Atwill, UC Davis School of Veterinary Medicine professor and co-principal investigator of the newly funded study; and principal investigator Robert Mandrell, research leader of the USDA-Agricultural Research Service Produce Safety and Microbiology

A joint UC Davis/ USDA research project will sample crops in the Salinas Valley, as well as animal droppings and water. Genetic tests will be used to "fingerprint" and track bacterial contaminants such as E. coli 0157:H7.

\begin{tabular}{|c|c|c|c|}
\hline \multicolumn{4}{|c|}{$\begin{array}{l}\text { Selected categories of foodborne-disease outbreaks, } \\
\text { cases and deaths in the United States, 1998-2002* }\end{array}$} \\
\hline & Outbreaks & Cases & Deaths \\
\hline \multicolumn{4}{|l|}{ Bacterial } \\
\hline Campylobacter & 61 & 1,440 & 0 \\
\hline Clostridum perfringens & 130 & 6,724 & 4 \\
\hline Escherichia coli & 140 & 4,854 & 4 \\
\hline Listeria monocytogenes & 11 & 256 & 38 \\
\hline Salmonella & 585 & 16,821 & 20 \\
\hline Shigella & 67 & 3,677 & 1 \\
\hline Staphylococcus aureus & 101 & 2,766 & 2 \\
\hline Vibrio parahemolyticus & 25 & 613 & 0 \\
\hline Other & 65 & 736 & 1 \\
\hline Total & 1,185 & 37,887 & 70 \\
\hline \multicolumn{4}{|l|}{ Parasitic } \\
\hline Cryptosporidium parvum & 4 & 139 & 0 \\
\hline Cyclospora cayetanensis & 9 & 325 & 0 \\
\hline Giardia intestinalis & 3 & 119 & 0 \\
\hline Other & 7 & 47 & 0 \\
\hline Total & 23 & 630 & 0 \\
\hline \multicolumn{4}{|l|}{ Viral } \\
\hline Hepatitis A & 50 & 981 & 4 \\
\hline Norovirus & 657 & 27,171 & 1 \\
\hline Other & 2 & 122 & 0 \\
\hline Total & 709 & 28,274 & 5 \\
\hline \multicolumn{4}{|l|}{ Total (including } \\
\hline \multicolumn{4}{|c|}{$\begin{array}{l}\text { * The source of this data is the U.S. Centers for Disease Control and } \\
\text { Prevention, MMWR Surveillance Summaries. }\end{array}$} \\
\hline \multicolumn{4}{|c|}{$\begin{array}{l}\text { Columns do not add up because totals also include } 59,389 \text { cases of } \\
\text { disease with unknown origin, } 1,060 \text { cases of disease with multiple } \\
\text { origins as well as } 1,140 \text { cases of disease caused by chemical toxins, } \\
\text { none of which are listed here. }\end{array}$} \\
\hline
\end{tabular}


Research Unit. "The pigs are interesting to us now based on what we know about them, but we need to deal with facts," Mandrell says. "Wild pigs and other animals have to be studied more extensively to determine where the bacteria really are residing."

Scientists will carefully analyze the findings to identify which vertebrates are sources of $E$. coli O157:H7; assess the climate, landscape attributes and irrigation practices; and determine whether con-

\section{Scientists test for E. coli 0157:H7 in Salinas Valley}

For the last 5 years, UC researchers conducting on-farm tests of lettuce, soil, irrigation water and runoff in the Salinas Valley did not detect any of the virulent $E$. coli O157:H7 bacteria that caused the September 2006 spinach outbreak.

UC Davis postharvest specialist Trevor Suslow and Monterey County farm advisor Steve Koike conducted hundreds of tests. "We have demonstrated that populations of nonpathogenic E. coli on lettuce in the majority of fields is very low," Suslow says. "To this date, we have never encountered detectable levels of viable, pathogenic E. coli using methods of high sensitivity and specificity."

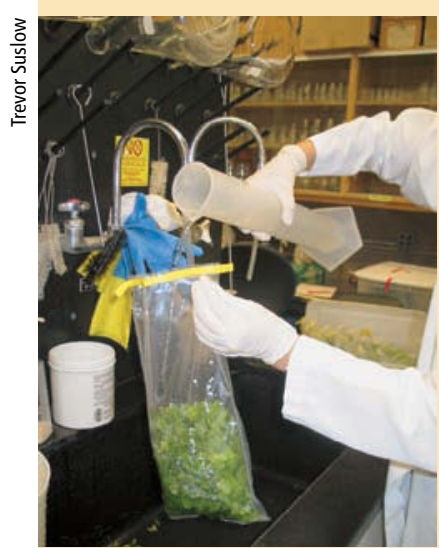

Hundreds of tests conducted in Salinas Valley lettuce fields did not detect any E. coli O157:H7.
However, since 1995, more than 15 illness outbreaks have been associated with lettuce or spinach consumption in the United States and Canada - and several have been traced to the Salinas Valley.

"We know that detectable levels of pathogenic E. coli have been found outside the farm, for instance in watersheds and drainage creeks - water sources that are not used for irrigation," Suslow says. "E. coli O157:H7 clearly occurs in the natural environment, and there are natural events such as wild animal movements or flooding that could introduce these pathogens to farmed land. The challenge is to learn whether and how they may survive, and develop management practices that protect food production areas from contamination."

In evaluating various E. coli O157:H7 detection methods, the researchers also found that several commercially available rapiddetection testing kits routinely gave "false positive" results. "An incorrect interpretation of results from these end-point tests could cause growers a lot of problems," Koike says.

The study, funded by the California Lettuce Research Board, has helped the scientists develop baseline microbiological indicator data for irrigation water, soil survival and lettuce, and has led to better understanding of the variability among fields and common crop production practices, Koike says.

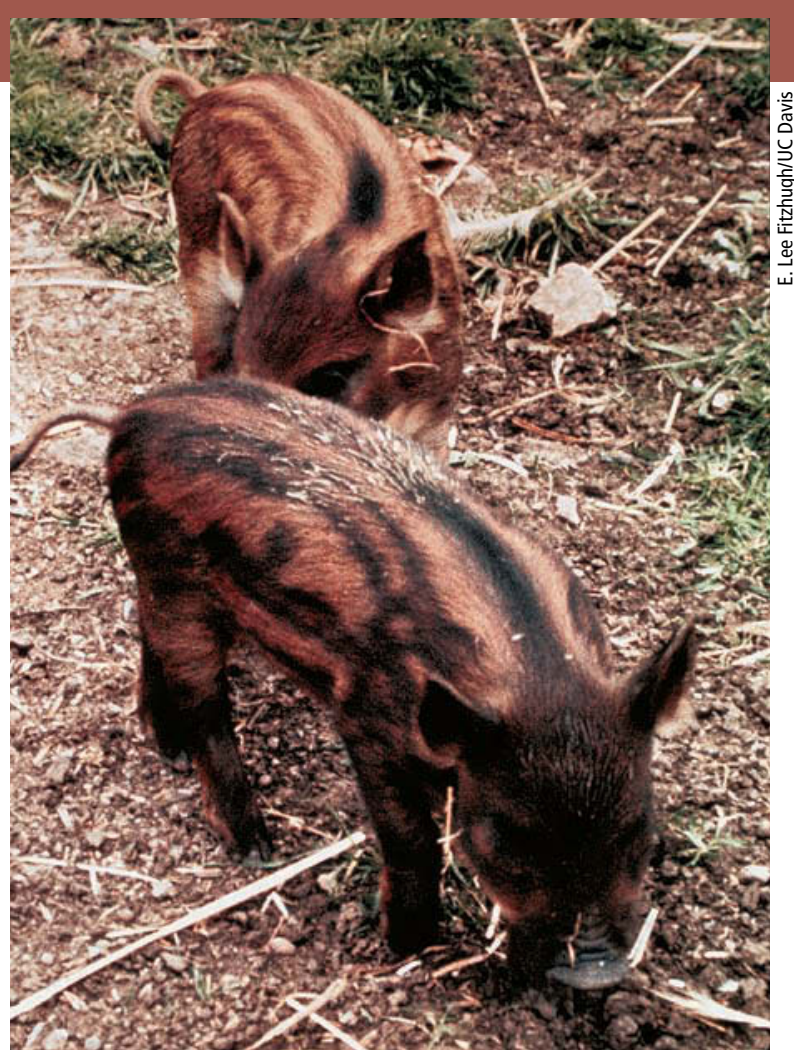

Following the September 2006 outbreak of foodborne illness linked to E. coli 0157:H7 in fresh spinach, state health investigators speculated that wild pigs may have transported the pathogen from infected cattle into fields.

taminated produce is associated with certain farming practices or environmental factors.

The researchers will use two sophisticated tests - MultiLocus Variable tandem repeat Analysis (MLVA) and Pulsed Field Gel Electrophoresis (PFGE) - to "fingerprint" and track bacteria. PFGE is the same process used by the CDC to discover whether strains responsible for human illnesses - and potentially associated with foodborne disease outbreaks - are related to one another, as was true in the case of spinach in September 2006. MLVA is a method for determining the genetic similarities among strains, allowing scientists to better understand how strains are related.

"Most strains of E. coli O157:H7 bacteria are so similar that we need to look at the genome to accurately trace the sources and transport of strains through the environment," Mandrell says.

Ultimately the scientists hope to tease out links between management practices, environmental conditions and vertebrates that carry the deadly bacteria. And then, the researchers will develop intervention strategies that sever the links.

More than three-quarters of California's total production of salad greens comes from the Monterey County region, including the majority of the lettuce produced for the U.S. market, which is valued at $\$ 1.3$ billion annually. - Jeannette Warnert and Editors 